\title{
Tribodiagnostic Analysis of Motor Oil after Failure of Turbocharger of Combustion Engine
}

Jindřich Pavlů${ }^{1}$, Vladimír Hönig ${ }^{2}$, Zdeněk Aleš $^{1}$, Rostislav Chotěborský1

${ }^{1}$ Faculty of Engineering, Czech University of Life Sciences Prague. Czech Republic. E-mail: pavluj@tf.czu.cz, ales@tf.czu.cz, choteborsky@tf.czu.cz

${ }^{2}$ Faculty of Agrobiology, Food and Natural Resources, Czech University of Life Sciences Prague. Czech Republic. Email: honig@af.czu.cz

Microscopy is mainly used in tribotechnical diagnostics for the analysis of the total number and morphology of the wear particles in the lubrication systems. Wear particles may accelerate wear and ultimately may cause a failure in lubricating systems. Therefore, this paper deals the tribodiagnostic problem which is focused on microscopic analysis of wear particles and additional tribodiagnostic analysis of motor oil. There was taken sample of motor oil after failure of turbocharger of combustion engine. The purpose of the paper is to compare the results of microscopic analysis for evaluation of wear particles in motor oil. These analyses are key for assessing wear of the combustion engine and for indicating of impending failure. The aim of this experiment was to assess hypothesis that scanning electron microscopy (SEM) is appropriate for tribology diagnostics of seized turbocharger of internal combustion engine.

Keywords: Scanning Electron Microscopy, LaserNetFines, Wear Particles Morphology

\section{Acknowledgement}

Paper was created with the grant support - IGA CULS Prague 2016: 31190/1312/3117 Effect of mixtures of biofuels on production of nitrogen oxide and smoke of combustion engine during NRSC.

\section{References}

[1] ALEŠ, Z., PAVLŮ, J., MÜller, M., SVOBODOVÁ, J., LEBEDEV, A., YUROV, A., PEXA, M., LINDA, M., (2016). Influence of Abrasive - Free Ultrasonic Finishing Process of Steel on Wear. Manufacturing Technology. 16 (1). pp. 4-12.

[2] ANDERSON, D. P. (1982). Wear Particle Atlas: Revise. Naval Air Engineering Center, Lakerhurst, New Jer-sey, NAEC 92-163.

[3] BHUSHAN, B. (2001). Modern tribology handbook. Boca Raton. FL: CRC Press. ISBN 0849384036.

[4] CHOTEBORSKY, R., LINDA, M. (2016). Determination of chemical content of soil particle for abrasive wear test. (2016) Agronomy Research, 14, pp. 975-983.

[5] GIAKOUMIS. E. G. (2010). Lubricating oil effects on the transient performance of a turbocharged diesel engine. Energy. 35 (2), pp. 864-873.

[6] JURÁNEK, R., MACHALÍK, S., ZEMČÍK, P. (2011) Research on image features for classification of wear debris. Machine Graphics and Vision, 20 (4), pp. 479-493.

[7] LÜDDECKE, B., NITSCHKE, P., DIETRICH, M., FILSINGER, D., BARGENDE, M. (2016). Unsteady thrust force loading of a turbocharger rotor during engine operation. Journal of Engineering for Gas Turbines and Power, pp. 138

[8] MÜller, M., LEBEdEV, A., SVOBOdovÁ, J., NÁPRSTKOVÁ, N., LEBEDEV, P. (2014). Abrasive-free ultrasonic finishing of metals. In: Manufacturing Technology. Vol. 14. pp. 366-370.

[9] NOVÁK, M. (2012). Surfaces with high precision of roughness after grinding. In: Manufacturing technology. Vol. 12. pp. $66-70$.

[10] PIRRO, D. M., WESSOL, A. A., WILLS, J.G. (2001). Lubrication fundamentals. 2nd ed. rev. and expanded. New York: Marcel Dekker. Mechanical engineering. pp 578. ISBN 0824705742. 